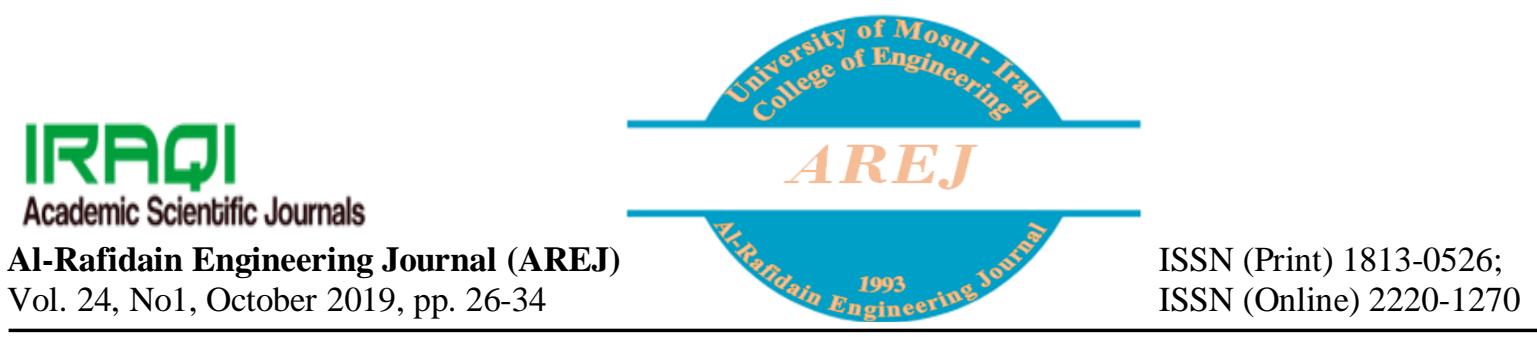

\title{
Neighborhood Sustainability Evaluation Based on UN-Habitat ... Principles: Case Study Masike and Avro city in Duhok
}

\author{
Dr.Layla M. Raswol \\ laylaraswol@yahoo.de \\ Architecture Engineering Department, Nawroz University, Duhok \\ Architecture Engineering Department, University of Duhok
}

Received: 24-2-2019

Accepted: 30-4-2019

\begin{abstract}
The aim of this research is to introduce guidelines and concepts to optimize the urban Design and planning for residential area and to contribute to the sustainable housing development in Kurdistan cities. The Housing Sector as one of the most important sectors in the city development has facing a lot of challenges in terms of sustainability due to the rapid population growth in cities of Iraqi Kurdistan. The city of Duhok as an example of other cities in the region has experienced dynamic urban growth in the last decades as a result of the unstable political and economic conditions in the Region. The local government has tried to cover housing shortage by many strategies such as plot distribution as well as supporting investors to provide housing units to meet people 's housing need. The main research objective is to evaluate the urban sustainability of the selected neighborhoods in the new developed area of Duhok city. The research used the principles of UN- Habitat for analyzing neighborhood sustainability by quantitative measurement of: efficient streets network, high density, mix use, social mix and limited land use specialization. The research outcomes indicate that there is an urgent need to direct the urban growth to more walkable mixed land use neighborhoods rather than car-oriented development by integrating the urban sustainability principles in the new housing projects to create healthier living environment for the residents.
\end{abstract}

Keywords:

Urban Development; Neighborhood Sustainability; UN-Habitat; Duhok city

https://rengj.mosuljournals.com

Email: alrafidain_engjournal@umosul.edu.iq

\section{INTRODUCTION}

1. Theoretical Background

1.1 Sustainable urban development

The rapid urban growth in developing countries leads to facing many challenges to meet the demand of the growing urban population. The major features for growing cities are urban sprawl, inefficient land use, high car dependency, low density and fragmented urban spaces (UNHabitat 2014). Sustainable development is defined by the Brundtland Report (WCED 1987) of the World Commission on the Environment and Development as "the development that meets the needs of the present without sacrificing the ability of future generations to meet their own needs". Hence, the concept of sustainable urban development has been defined by researcher to achieve livability, efficiency, affordability and environmentally friendly community.

The urban sustainability is the process of minimizing natural resource consumption and improving the urban environment, economic and promotes equity by socially integrated and environmental friendly development through high density, diversity with mixed land use, promoting nodes and green public space that are easier to walk and cycle (Jabareen, 2006; Martino, 2009; Friedman, 2007; Jenks, \& Dempsey, 2005)

1.2 Principles of sustainable neighborhood development

The neighborhood was described by Clarence Perry (1929) as a basic unit of city planning that should cover both dwellings and 
their environment including all public facilities and conditions required by the family for its comfort. The urban planners need to ensure the availability of diverse activities in the neighborhood in a walkable distance rather than a driving one. (Friedman, A. 2007) argues that the design of walkable neighborhood must regard the needs of pedestrians, cyclists and drivers equally. The efficient sidewalks and paths may link the housing units with the social and commercial amentias in safer and comfortable way by creating a pleasant landscape with trees and shading benches. On the other hand, the high dense and mixed land use residential areas are more economic to serve, they provide a wide choice of facilities within easy reach by walking and cycling, which lead to environmental and social benefits (Towers, 2005; Jenks-Jones, 2010). Based on this Background the UN Habitat defines the key features for sustainable neighborhoods to be compact, integrated and connected by applying five principles for sustainable neighborhoods: efficient streets networks, high density, mixed land use, social mix and Limited land use specialization.

The main objectives of these five principles are to create livable and efficient neighborhoods by promoting high density to reduce urban sprawl and service costs, creating vibrant street life, encouraging walkability to reduce car dependency and providing diverse housing types as well as mixed land use by using different function (residential, commercial, offices etc.) in one neighborhood to pr. Table (1) shows the quantitative measurements of the five principles. This research will use these principles to analyze and evaluate the sustainability of the new developed neighborhoods in the study area.

\section{Study Area}

1.3 Challenges of housing development in Duhok

The Cities in Kurdistan have experienced dynamic urban development in the last decades as a result of the high socioeconomic development as well as the fact that the region provides a safe place for many people from other parts of Iraq. The growth rate of the urban population in Duhok governorate increased from $43 \%$ in 1977 to $75 \%$ in 2014 (KRSO 2018). The rapid population growth leads to increasing the demand of housing units. According to the Ministry of Planning there is a significant housing deficit in Kurdistan.

\begin{tabular}{|c|c|c|}
\hline Principle & Formula & $\begin{array}{l}\text { UN- } \\
\text { Hab } \\
\text { itat }\end{array}$ \\
\hline $\begin{array}{l}\text { Efficient } \\
\text { Street } \\
\text { networks }\end{array}$ & $\frac{\text { Street land-use }}{\text { Total floor area }}$ & $\begin{array}{l}30- \\
45 \%\end{array}$ \\
\hline $\begin{array}{l}\text { High } \\
\text { Density }\end{array}$ & Population density & $\begin{array}{l}150- \\
600 \\
\text { p/ha }\end{array}$ \\
\hline \multirow[t]{2}{*}{$\begin{array}{l}\text { Mix Land } \\
\text { Use }\end{array}$} & $\frac{\text { Economic floor area }}{\text { Total floor area }}$ & $\begin{array}{l}40- \\
60 \%\end{array}$ \\
\hline & $\frac{\text { Residential floor }}{\frac{\text { area }}{\text { Total floor area }}}$ & $\begin{array}{l}30- \\
50 \%\end{array}$ \\
\hline \multirow[t]{2}{*}{ Social mix } & $\begin{array}{l}\frac{\text { Single tenure }}{\text { Residential }} \\
\text { area }\end{array}$ Floor & $\begin{array}{l}0- \\
50 \%\end{array}$ \\
\hline & $\begin{array}{l}\text { Affordable housing } \\
\text { Residential floor } \\
\text { area }\end{array}$ & $\begin{array}{l}20- \\
50 \%\end{array}$ \\
\hline $\begin{array}{l}\text { Limited } \\
\text { Function } \\
\text { Specializati } \\
\text { on }\end{array}$ & $\frac{\text { Single function }}{\frac{\text { block area }}{\text { Neighborhood area }}}$ & $\begin{array}{l}0- \\
10 \%\end{array}$ \\
\hline
\end{tabular}

There was a need to produce 250,000 housing units by the year 2016 (Kurdistan Regional Government-Ministry of Planning, 2011). The demand for housing in Duhok city was 43,032 units in 2012 and 50,600 units in 2017 (Mumtaz, 2012). The local government has tried to cover this shortage by many housing strategies such as supporting the employee with plot distribution as well as encouraging investors (Investment law No. 4 2006) to provide housing project for the people in the new developed area of the city. However, the inefficiency of housing policies in KRG caused a shortage in providing the affordable housing units for the people in the region (Ali, 2016). Researches confirm that the results of the rapid expansion of residential area in Duhok are loss of surrounding agriculture land, increasing pollution, inefficiency in providing infrastructure, increasing poverty and informal housing area (Omer 2016). The report of Iraq national housing policy (2010) listed the main challenges of housing sector in the region as following; providing sufficient quantities of 
affordable housing to meet the needs of the growing population; improving the land management system to make land sites available for residential need; lack of formal housing finance; lack of Infrastructure services in many residential areas (MOCH 2010). To respond to these challenges this research is trying to introduce concepts and principles of sustainable neighborhood. The main research objective is to evaluate the physical planning of the new existing neighborhoods through urban sustainability principles to provide guidelines for increasing the efficiency of housing production and to reduce the negative impact of the rapid urban development.

\section{Research Methodology}

The research selects two new developed residential areas in Duhok with different pattern and typologies to represent the new trends of residential expansion in the city and to have a good overview of the new housing area in the city. The methods used for data collection are: analyzing the maps and the data gained from the related governmental institutions, on-site observation in the selected case studies and random interviews with residents. The UNHabitat principles of sustainable neighborhoods to be compact, integrated, and connected were considered to be applied in the new developing neighborhoods in Duhok. Accordingly, the following principles of UN-Habitat (see table 1) are used as quantitative measurements to analyze and evaluate the urban sustainability of the neighborhoods:

1. An efficient street networks: that should occupy $30-45 \%$ of neighborhood total area.

2. High density: at least $150 \mathrm{p} / \mathrm{hectare}$.

3. Mixed Land use: at least $40-60 \%$ of the total should be for economic use in the

\begin{tabular}{|l|l|}
\hline \multicolumn{2}{|l|}{$\begin{array}{l}\text { Table 2: Description of Case Study } 1 \text { based on } \\
\text { the data of the Municipality of Duhok } 2019\end{array}$} \\
\hline Case Study 1 (Masike) & $\begin{array}{l}\text { Unite } \\
\text { (hectare) }\end{array}$ \\
\hline Neighborhood area & 209.8 \\
\hline Neighborhood buildup area & 118.5 \\
\hline Residential floor area & 87.22 \\
\hline Green area & 14.9 \\
\hline Economic use floor area & 31.28 \\
\hline Streets Networks area & 76.4 \\
\hline
\end{tabular}

neighborhood

4. Social mix: at least 20 to $50 \%$ of the total floor area should be for affordable housing.

5. Limited land use specialization: less than $10 \%$ of any neighborhood area should cover single function to introduce mixed land-use zoning and promote mix neighborhoods

\section{Analysis of Case Studies}

The selection of the case studies depends on two criteria: the rate of the development and the housing typology in order to have a good understanding about the current condition of housing development in the city. The two selected case studies are Masike as a neighborhood of one family houses, which is formally planned by the local municipality of Duhok in 2008and the 200 sqm plots were developed by the inhabitants. The second case is Avro city as a neighborhood of multi-family housing units, which is planned and developed by the private sector since 2007 supported by Kurdistan government investment law 4 of 2006.

\subsection{Masike}

Masike neighborhood is located in North West of Duhok city about $5.6 \mathrm{~km}$ away from the city center. Originally it was a village called Masike included in the expanded city master plan. Since 2008 the area developed rapidly. Table (2) shows the main data about the size of the neighborhood. The total area is about 209.8 ha. The population size in the neighborhood is around 25240 persons based on the number of the planed plots and the size of the family in Duhok (GIZ department, Municipality of Duhok, 2019). Currently the neighborhood has largely developed consisting of the commercial, social services such as schools, health care unit, mosque, and church as well as oil station and fire protection station. The neighborhood is typical plot neighborhood planned by the municipality as detached side by side /back to back 200 sq. m plots. The number of the plots is about 4240 planned in 212 linear residential blocks. The plots were developed from the residents mostly private single-family houses. (Fig.1) shows the land use map. The mix use building located at the main Road including commercial function and the social services located in the center. (Fig 2) shows the buildup area which represents about $56 \%$ of the total area. The open green space covers $7 \%$ of the total area and is distributed hierarchically in the neighborhood (Fig.3). (Fig 4) shows the streets pattern, which covers $36.4 \%$ from the total area designed hierarchically from major street $(30 \mathrm{~m})$ to home zone $(10 \mathrm{~m})$. 


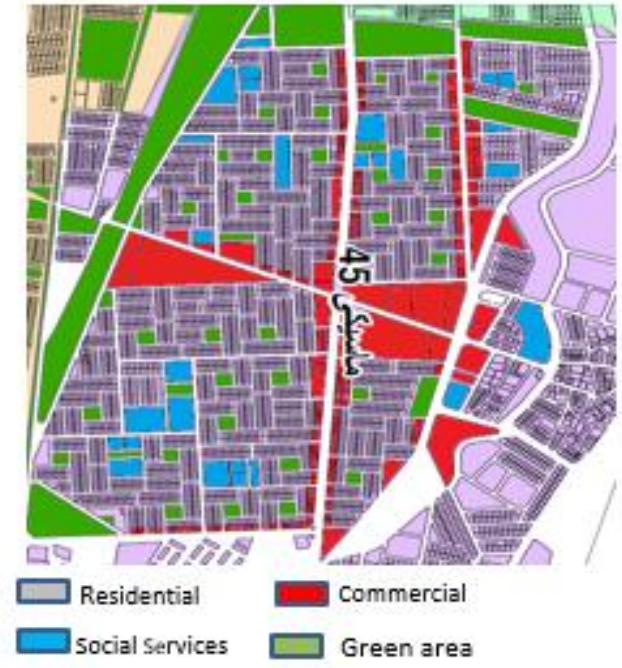

Fig 1 The Land use (Author)

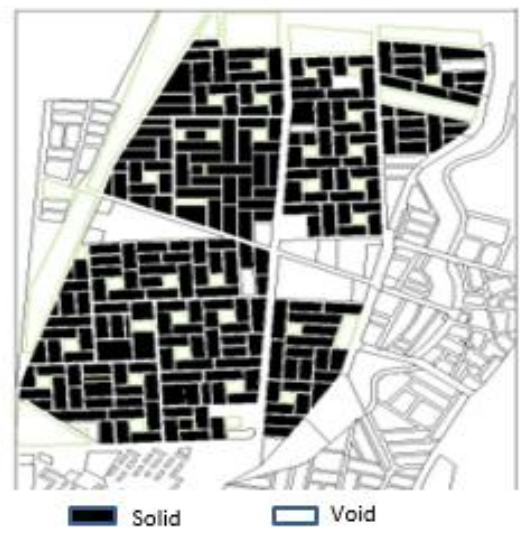

Fig 2 The Buildup area (Author)

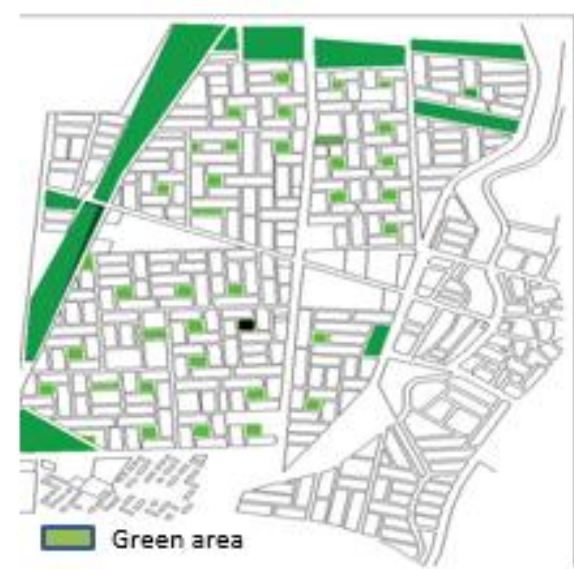

Fig 3 The green area concepts (Author)

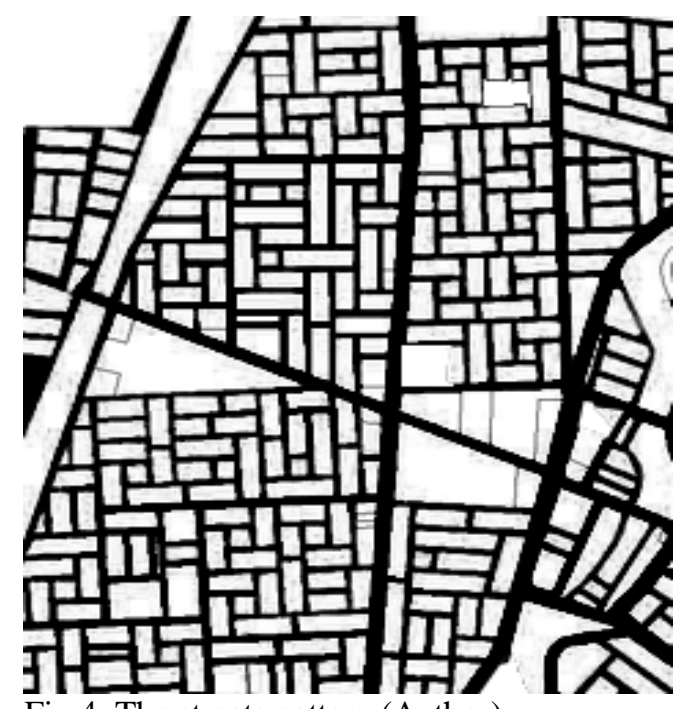

Fig 4: The streets pattern (Author) 
Table 3: Analysis of Masike sustainability based on

UN Habitat principles

\begin{tabular}{|c|c|c|c|}
\hline Principle & Formula & $\begin{array}{c}\text { Standard } \\
\text { S } \\
\text { UN- } \\
\text { Habitat }\end{array}$ & $\begin{array}{c}\text { Masik } \\
\text { e }\end{array}$ \\
\hline $\begin{array}{l}\text { Efficient } \\
\text { Streets }\end{array}$ & $\begin{array}{l}\frac{\text { Street land- }}{\text { use }} \\
\text { Total } \\
\text { neighborhoo } \\
\text { d area }\end{array}$ & $(30-45 \%)$ & $\begin{array}{c}(36.4 \% \\
)\end{array}$ \\
\hline $\begin{array}{l}\text { High } \\
\text { Density }\end{array}$ & $\begin{array}{l}\text { Population } \\
\text { density }\end{array}$ & $\begin{array}{c}(150- \\
600 \mathrm{p} / \mathrm{ha})\end{array}$ & $\begin{array}{l}(120 \\
\mathrm{p} / \mathrm{ha})\end{array}$ \\
\hline \multirow{2}{*}{$\begin{array}{l}\text { Mix Land } \\
\text { Use }\end{array}$} & $\begin{array}{c}\frac{\text { Economic }}{\text { floor area }} \\
\begin{array}{c}\text { Total floor } \\
\text { area }\end{array}\end{array}$ & $(40-60 \%)$ & $26.3 \%$ \\
\hline & $\frac{\frac{\text { Residential }}{\text { floor area }}}{\begin{array}{c}\text { Total floor } \\
\text { area }\end{array}}$ & $(30-50 \%)$ & $\begin{array}{c}(73.6 \% \\
)\end{array}$ \\
\hline \multirow{2}{*}{ Social mix } & 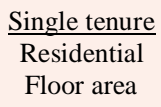 & $(0-50 \%)$ & $(100 \%)$ \\
\hline & $\begin{array}{l}\frac{\text { Affordable }}{\text { housing }} \\
\text { Residential } \\
\text { floor area }\end{array}$ & $(20-50 \%)$ & $(0 \%)$ \\
\hline $\begin{array}{c}\text { Limited } \\
\text { Function } \\
\text { Specializatio } \\
\mathrm{n}\end{array}$ & $\begin{array}{c}\frac{\text { Single }}{\text { function }} \\
\text { block area } \\
\begin{array}{c}\text { Neighborhoo } \\
\text { d area }\end{array}\end{array}$ & $(0-10 \%)$ & $85 \%$ \\
\hline
\end{tabular}

Table 4: Description of Case Study2 based on

\begin{tabular}{|l|l|}
\hline Case Study 2 (Avro City) & $\begin{array}{l}\text { Unite } \\
\text { (hectare) }\end{array}$ \\
\hline Neighborhood area & 89 \\
\hline Neighborhood buildup area & 38.8 \\
\hline Residential floor area & 28.4 \\
\hline Green area & 20.1 \\
\hline Economic use floor area & 10.4 \\
\hline Streets Networks area & 30.2 \\
\hline
\end{tabular}

the Data of the project manager 2019

Table (3) shows the analysis of the neighborhood according to UN-Habitat principles. The street network efficiency is adequate. The population density is lower than the standards $120 \mathrm{p} / \mathrm{ha}$. The residential floor area is larger than the standards and the economic floor area is less than standards. The housing tenures are $100 \%$ private ownership or rented houses from the residents themselves. The mixed used blocks are only on the major roads, where the owners invest in their buildings for economic activities. The main block function in the neighborhood is the residential blocks, which cover $85 \%$ of the total area.

\subsection{Avro City}

Avro city is a gated residential area in Duhok city, the project was developed since 2007 by private sector (Turkish company named Gurbag) supported by local government and investment law (Nr. 4 2006). Table (4) shows the main data about the size of the neighborhood. The total area of the residential project is about 89 hectares. The neighborhood is located near Duhok - Zakho highway. Avro city project consist of 4532 housing apartments and 93 Villas (Directory of housing and construction in Duhok). The population size of Avro city according to the directorate of statistic in Duhok city is 23300 people. (Directory of housing and construction Duhok 2019). The housing units are point multifamily housing units with different floor numbers from (7-12 floors). They have different sizes apartments from two bedroom (type A), three bedrooms (type B), four bedrooms (type C) as well as duplex apartments. The apartment buildings and villas are surrounded by good open green landscape and walkways for the resident to enjoy their time. The outdoors space provides many sport and children play grounds. (Fig. 5) shows the land use map. The complex includes social services such as kindergarten, nurseries, schools, health center as well as commercial activities and police station. The commercial services are only in the edge of the neighborhood and the social and public services are in the center of the neighborhood. The main streets are connected to parking area to access the housing units. The buildup area covers $43.5 \%$ of the total area. The access pattern is clear and well connected with the parking area for each housing unit. The streets area covers $33.9 \%$ of the total area. The open green space represents $22.5 \%$ of the total area. (Fig 6) shows the integration of green spaces in the neighborhood as court green area as well as green corridor along the housing units with walkable pathways and enjoyable landscape. 


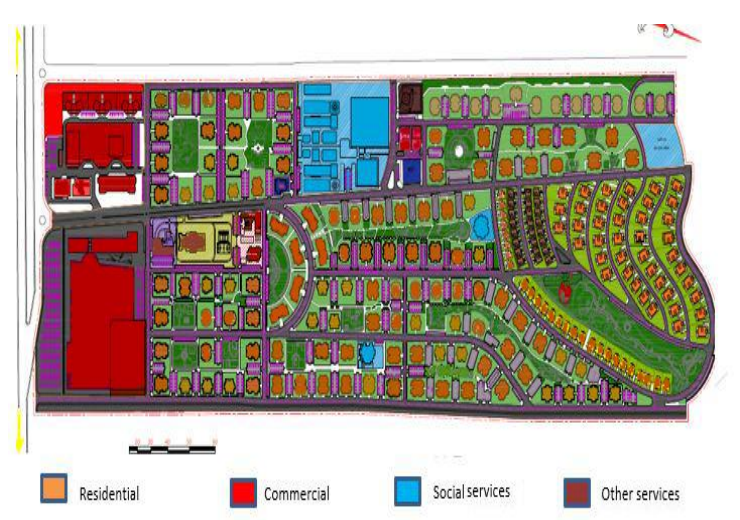

Fig 5: shows the land use map. (Author)

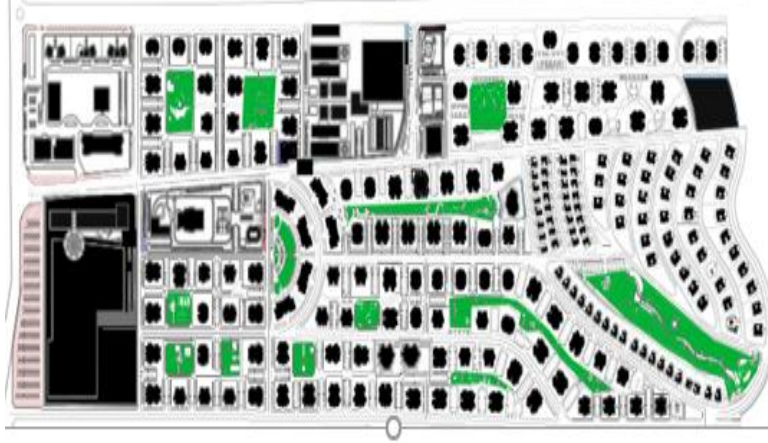

\begin{tabular}{|c|c|c|c|}
\hline Principle & Formula & $\begin{array}{l}\text { Standa } \\
\text { rds } \\
\text { UN- } \\
\text { Habitat }\end{array}$ & $\begin{array}{l}\text { Avr } \\
\text { o } \\
\text { City }\end{array}$ \\
\hline $\begin{array}{l}\text { Efficient } \\
\text { Streets }\end{array}$ & $\begin{array}{l}\frac{\text { Street }}{\text { land-use }} \\
\text { Total } \\
\text { neighborh } \\
\text { ood area }\end{array}$ & $\begin{array}{l}(30- \\
45 \%)\end{array}$ & $\begin{array}{l}33.9 \\
\%\end{array}$ \\
\hline $\begin{array}{l}\text { High } \\
\text { Density }\end{array}$ & $\begin{array}{l}\text { Population } \\
\text { density }\end{array}$ & $\begin{array}{l}(150- \\
600 \\
\text { p/ha })\end{array}$ & $\begin{array}{l}(250 \\
\mathrm{p} / \mathrm{ha}\end{array}$ \\
\hline \multirow[t]{2}{*}{$\begin{array}{l}\text { Mix Land } \\
\text { Use }\end{array}$} & $\begin{array}{l}\frac{\text { Economic }}{\text { floor area }} \\
\text { Total floor } \\
\text { area }\end{array}$ & $\begin{array}{l}(40- \\
60 \%)\end{array}$ & $\begin{array}{l}26.8 \\
\%\end{array}$ \\
\hline & $\frac{\frac{\text { Residentia }}{\text { floor area }}}{\begin{array}{l}\text { Total floor } \\
\text { area }\end{array}}$ & $\begin{array}{l}(30- \\
50 \%)\end{array}$ & $\begin{array}{l}73.2 \\
\%\end{array}$ \\
\hline \multirow[t]{2}{*}{ Social mix } & $\begin{array}{l}\frac{\text { Single }}{\text { tenure }} \\
\text { Residentia } \\
1 \quad \text { Floor } \\
\text { area }\end{array}$ & $(0-50 \%)$ & $\begin{array}{l}100 \\
\%\end{array}$ \\
\hline & $\begin{array}{l}\text { Affordable } \\
\text { housing } \\
\text { Residentia } \\
1 \text { floor area }\end{array}$ & $\begin{array}{l}(20- \\
50 \%)\end{array}$ & $0 \%$ \\
\hline $\begin{array}{l}\text { Limited } \\
\text { Function } \\
\text { Specializat } \\
\text { ion }\end{array}$ & $\begin{array}{l}\frac{\text { Single }}{\text { function }} \\
\frac{\text { block area }}{\text { Neighborh }} \\
\text { ood area }\end{array}$ & $(0-10 \%)$ & $89 \%$ \\
\hline
\end{tabular}

Fig 6: Shows the buildup area and the green concept (Author)

Table (5) shows the analysis of the neighborhood according to UN-Habitat principles. The street networks efficiency is adequate. The neighborhood has suitable population density $250 \mathrm{p} / \mathrm{ha}$. The economic floor area is very low. The housing tenures are private with different sizes and prices but not affordable housing. The limited function block concept is not involved and there is lack of mixed-use function since the residential function blocks present about $90 \%$ of the neighborhood area.

Table 5: Analysis of the Avro city based on UNHabitat principles

\section{Results Discussion}

Both neighborhoods are formally planned and developed from the municipality and private sector. They have different pattern of land use and mostly residential function. The findings discussion will focus on the main elements of neighborhoods that are defined in the theoretical part of the study, which are efficient streets networks, high density, mix land use, social mix (mix housing types), Limited function specialization (Limited single function blocks). 


\subsection{Efficient Streets network}

The streets networks in both neighborhoods are sufficient. The ratio of the streets land use area in both case studies are efficient and in the range of the UN- Habitat standard. The main characteristics of effective streets network are interconnected streets hierarchy, safe walkability and cyclist friendly, availability of sufficient parking places and public transport. Both case studies have an easy access and the streets are well connected. The public transportation such as taxis and buses are nearby, which are the most available public transports in the region, however most of the residents use their private car to go to work, which impact negatively on the environment and cause pollution and overcrowding. According to the sites visits and interviews the residents in Masike are not satisfied with the walkability of the neighborhood because of the not well constructed pathways and poor quality of sidewalks (Fig 7). Meanwhile the observation finding in Avro city shows that the residents are satisfied with the walkability of the neighborhood, the level of walkability in the area is high because of the enjoyable landscape and safe pathways (Fig 8).

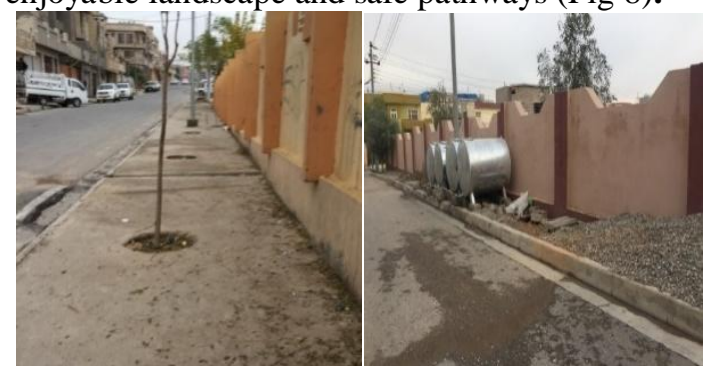

Fig. 7: Shows poor quality of pathways in Masike (Author)

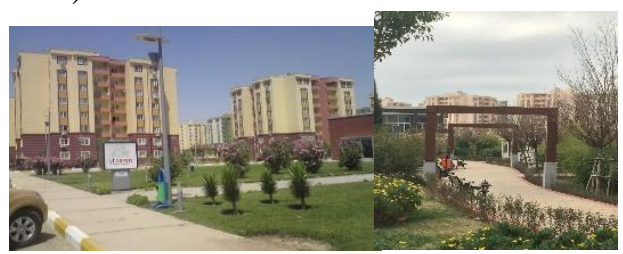

Fig. 8: Shows pathways in Avro city (Author)

\subsection{High density}

The Case of Avro city shows suitable population density $250 \mathrm{p} / \mathrm{ha}$ in comparison to Masike 120p/ha. The low density in Masike is a result of the single-family houses on private plots, which distributed from the municipality to government employee to solve their housing need, but the development of the plots depends on the financial ability of the owner. The multifamily houses as a high neighborhood has economic, social and environmental benefits such as; promoting efficient land use; avoid urban sprawl; provide more housing units per area; reduce costs of public services such as roads, schools and other infrastructure; reduce car dependency and pollution; increase walkability as well as energy efficiency and better living environment (UNHabitat 2014).

\subsection{Mixed Land use}

According to the findings the mixed land uses in the case studies are located mostly on the edge of the neighborhood and alongside of the main streets. Mixed land use combines the residential area with commercial, office and public services. The mix land use creates more walkable community. The residents in Masike case study are satisfied with availability of mix use urban activities in the neighborhood nearby, which attract the people and encourage walking. Meanwhile, the design of mixed land uses should be studied carefully to avoid noise, pollution and protect the healthy environment. According to the finding the residents confirm that the mixed uses activities on the main streets create a high level of noise, pollution and overcrowding particularly for the residents, who are living in the mixed uses building on the main commercial roads (Fig.9). On the other hand, the residents in Avro city complain about the lack of mixed-use services, which cover only $10 \%$ of the total area and are mostly not developed from the investor. Fig (10) shows the only existing mix used area in the complex. It locates near the main gate and the service is limited to the surrounding housing building.

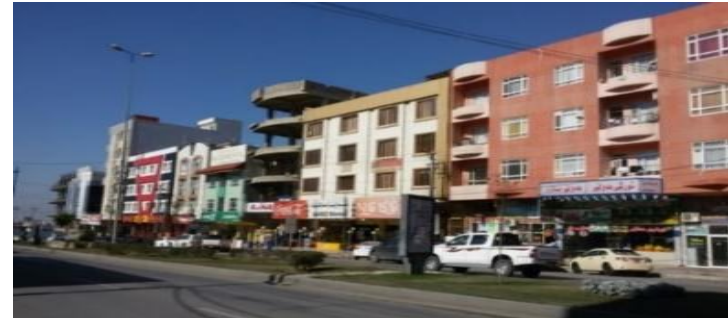

Fig. 9: shows the mix used in Masike(Author)

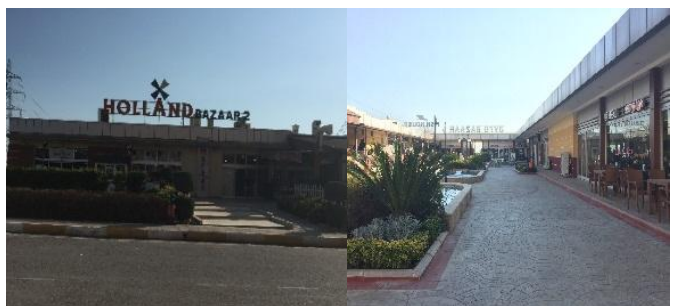

Fig. 10: shows the mix used inAvro City (Author)

\subsection{Social mix}


The finding of the Analysis of both cases shows that the social mix approach is not available. The tenure in both cases is private ownership and there are no public housing units. In Masike case study the plots have the same size (200 sqm), while the case Avro city provide diverse type of apartments in different sizes but their prices are not affordable for all social classes. The aim of social mix neighborhood is to enhance the cohesion and interaction between different social classes by providing diverse types of housing and promote mix neighborhood. The social mix can be achieved by enhancing public housing and providing plots in different sizes to increase housing diversity.

\subsection{Limited function specialization}

The aim of limiting functional zoning is to integrate the concept of mix land use zoning by careful design according to population needs to reduce car dependency and promote neighborhood livability. The findings show that in both case studies the concept of mixes neighborhood is not well involved. The mixeduse function in Avro city represent only 10\% from the neighborhood area and it is still vacant and not developed, while in Masike the ration of them is better $(15 \%)$, but it is located mostly along the main streets. It means that the special functional zoning in both case studies is not limited. The residential function blocks present $85 \%$ in Masike and $89 \%$ in Avro city. The UNHabitat (2014) recommend that less than $10 \%$ of any neighborhood should cover single function use zoning to provide a combination of residential, commercial, industrial, offices and other uses.

\section{Conclusion and recommendation}

The main measuring indicators of $\mathrm{UN}$ Habitat are used in this research to determine sustainable housing development which are: efficient streets with safe and comfortable paths; high dense to save services and infrastructure cost with less travel cost; Mix land use and diverse housing types to achieve social mix as well as limited function specialization to promote mix neighborhood. Two different neighborhoods in the new developed area in Duhok City were selected to apply UN- Habitat principles. The research concludes that both neighborhoods are facing critical problems in term of sustainability. The multifamily housing project meets some of
UN Habitat measurements indicators such as high density and efficient streets network better than the single-family housing. However, there is lack of mix land use and diverse housing types particularly the affordable housing to meet people needs. The research indicates that the housing development in Duhok city needs to apply the principles of sustainable neighborhoods strategies to balance population growth, economic growth and sustainable urban development. The urban planning and design of the housing projects needs to direct the urban growth to walkable neighborhoods rather than car dependency to be more vital and responding to the current demand of the growing population by providing well designed amenities in the residential areas such as economic and social activities as well as parks, green open spaces and sport activities in a walkable distance to encourage people to live there. The research recommends some guidelines for local authorities to be considered for the future housing projects:

- Establishing new urban planning system and creating legal framework for applying the five principles of sustainable urban development.

- Redefining and updating the Building code legislation to meet the international standards considering sustainability dimensions.

- Providing diverse housing types in the neighborhoods to be affordable for different social classes with different sizes to encourage social mix.

- Encouraging mix land-use in the neighborhood to meet community needs in a walkable distance by combining Housing, shops, offices and public services in land use zoning to encourage people to walk to the destination.

- Improving the streets efficiency and providing safe and pleasant streetscapes within the neighborhoods to improve the air quality, mitigate the negative impact of the growing development and add value to the built environment

- Encouraging public private partnership to provide public housing and involving the residents and private sector in improving the neighborhood living environment and creating collaborative programs for sustainable neighborhood. 


\section{References}

(1) Ali K. A. and Raswol, M. (2016) Planning for Affordable Housing Units in Duhok City, Zanco Journal for Pure and Applied Sciences, Salahadin University- Erbil

(2) Friedman, Avi (2007): Sustainable Residential Development. Mc Hill Companies, USA

(3) Jabareen, Y. R. (2006). Sustainable Urban Forms: Their Typologies, Models, and Concepts. Journal of Planning Education and Research

(4) Jenks, M. and Jones, C. (2010): Dimensions of the sustainable city 2, London: Springer

(5) Jenks, M., and Dempsey, N. (2005). Future forms and design for sustainable cities. Amsterdam.

(6) Kurdistan Regional Government-Ministry of Planning, 2011

(7) KRSO (2018): Demographic Survey Kurdistan Region in Iraq

(8) $\mathrm{MOCH}$ (Ministry of construction and housing in Iraq) (2010): housing Iraq national housing policy; prepared with Support of UN- Habitat, Iraq programs

(9) Mumtaz, B. (2012): Strategies to address low- income housing in KRG, $\mathrm{MOCH} \&$ UN-Habitat.

(10) Omer, M. Waheeda and Raswol (2016): The Effect of UGM on the Implementation of City Master Plan Duhok City as Case Study. Zanco Journal for Pure and Applied Sciences, Salahadin University- Erbil.

(11) Perry, C. (1929): The neighborhood Unit, Regional Plan of New York. New York, vol.III

(12) Towers, G. (2005): an introduction to urban housing design: at home in the city, Architectural Press. An imprint of Elsevier, Linacre House, Jordan Hill, Oxford OX2 8DP

(13) UN Habitat (2014), A new strategy of sustainable neighborhood planning: five principle, http://unhabitat.org/a-new-strategyof-sustaiable-neighborhood-planning-fiveprinciple/https://unhabitat.org/un-habitat-forthe-sustainable-development-goals/

\title{
تقييم إستدامة المجاورة السكنية في دهو ك بإعتماد مبادئ الأمم المتحدة

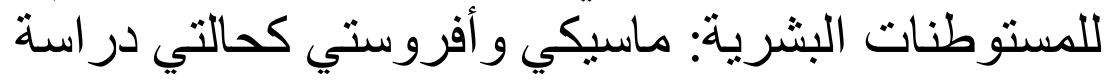

\author{
د.ليلى محمد رسول \\ مدرس مجد \\ laylaraswol@yahoo.de \\ قسم هندسة المعمارية، جامعة نوروز، دهوك

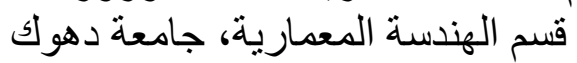

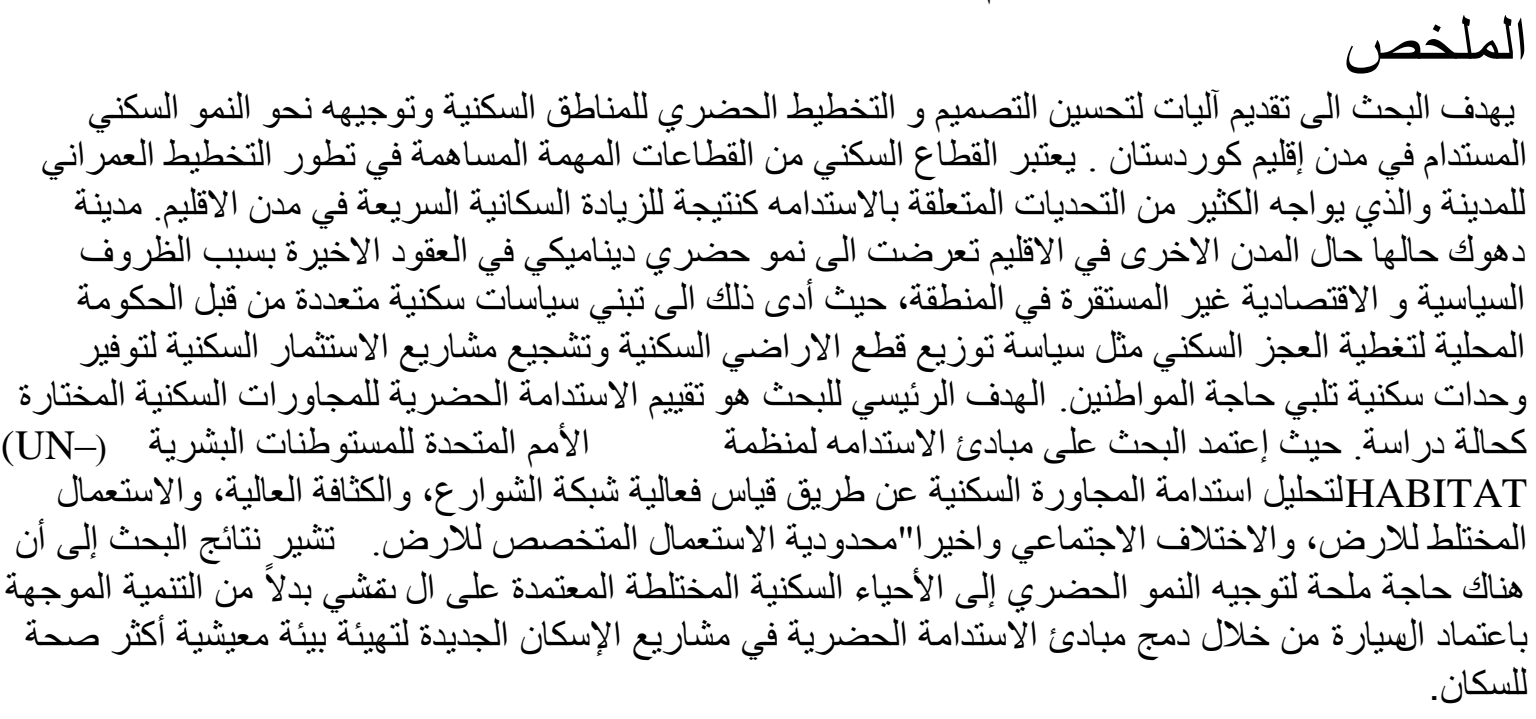

Al-Rafidain Engineering Journal (AREJ)

Vol. 24, No1, October 2019, pp. 26-34 
22 Layla M. Raswol: Neighborhood Sustainability Evaluation based on UN-Habitat ...

الكلمات الدالة: النمو السكاني، استدامة المجاورة السكنية، منظمة الأمم المتحدة للمستوطنات البشرية، مدينة دهوك. 